Geliș Tarihi: 19.10.2020

Kabul Tarihi: 03.05.2021
Mediterranean Journal of Humanities mjh.akdeniz.edu.tr XI (2021) 83-99

\title{
Cumhuriyetçi Özgürlük Anlayışı
}

\author{
Republican Conception of Freedom
}

Ekin KARABABA*

Öz: $\mathrm{Bu}$ makalede, Philip Pettit'in çağdaş cumhuriyetçiliğe katkılarını siyasal özgürlük bağlamında incelemeye çalışacağım. Tahakkümsüzlük olarak özgürlük şeklinde adlandırdığı kendi özgürlük yaklaşımını, müdahalesizlik olarak özgürlüğü eleştirerek ortaya koyan Pettit, tahakkümün her zaman toplumsal dayanakları olan bir güç ilişkisi olduğunu belirtir. Ona göre her türlü müdahale bireylerin özgürlüğünü tehdit etmez; ama tahakküme yol açan keyfi müdahalelerin sadece gerçekleşme riskinin var olması bile insanların özgürlüklerini azaltır. İlkinde keyfi olmayan müdahaleler kişilerin eylem seçeneklerini yalnızca niceliksel olarak azaltırken, ikincisinde onların eylem olanakları niteliksel olarak sınırlanır. Pettit'e göre, bir ideal olarak tahakkümsüzlük, kişilerin eylem olanaklarını niteliksel olarak arttırma amacında olduğu ve keyfi temelde olmayan müdahaleleri meşrulaştırabildiği için müdahalesizlik olarak özgürlükten üstündür.

Anahtar sözcükler: Cumhuriyetçilik, Özgürlük, Tahakküm, Tahakkümsüzlük, Müdahale, Philip Pettit.

\begin{abstract}
In this paper, I try to examine the contributions of Philip Pettit to contemporary republicanism in the context of political liberty. While criticizing 'freedom as non-interference' and asserting his approach of liberty as 'freedom as non-domination', Pettit indicates that domination is always a power relationship based on social conditions. According to him, not all interferences threat individual liberty; but even the potential danger of an interference on an arbitrary basis diminishes human freedom. In the first case interferences on an non-arbitrary basis decrease the choices of action only quantatively, while in the second, these choices are limited qualitatively. Pettit claims that non-domination is superior from noninterference as an ideal because it aims to increase the choices of action qualitatively and it can justify the interferences on an non-arbitrary basis.
\end{abstract}

Keywords: Republicanism, Freedom, Domination, Non-Domination, Interference, Philip Pettit.

\section{Giriş}

Isaiah Berlin, politik özgürlügün ne olduğu sorusunun, siyaset felsefesinin en önemli sorusu olduğunu söyler (Berlin 1958, 119). Çünkü her siyaset teorisinin, özgürlüğe dair kendine özgü bir yaklaşımı olması gerekir. Siyaset teorileri, hem politik olguları doğru olarak değerlendirme hem de politik olarak gerçekleştirilmesi gerekenlere dair uygun düşünceler ortaya koyma iddiasındadırlar. Fakat onların bu iddialarının altını doldurabilmeleri için politik özgürlüğün ne olduğu ve nasıl gerçekleştirilebileceği sorularına tatmin edici cevaplar vermiş olmaları gerekir.

\footnotetext{
*Arş. Gör. Muğla Sitkı Koçman Üniversitesi, Edebiyat Fakültesi, Felsefe Bölümü, Muğla, ekinkarababa@mu.edu.tr, https://orcid.org/0000-0003-3638-5937

Bu çalışma büyük oranda, 'Cumhuriyetçi Siyaset Teorisinde Özgürlük Problemine Dair Yapılan Tartışmalar' adlı yüksek lisans tezimin birinci ve ikinci bölümlerine dayanmaktadır.
} 
Politik bir yap1 içinde yaşayan bireylerin nasıl bir hayat sürüp süremeyeceklerine ya da nasıl yaşamaları ve nasıl yaşamamaları gerektiğine dair düşünceler ile bu bireylerin özgür olup olmadıklarına ve nasıl özgür olabileceklerine dair iddialar arasında doğrudan bir ilişki vardır.

Çağdaş cumhuriyetçilik (Çalışmanın devamında kısaca cumhuriyetçilik denilecek), günümüzdeki belirli politik sorunlara tatmin edici yanıtlar vermeye çalışan ve aynı zamanda ortaya attığı iddialar nedeniyle günümüzde hala yoğun olarak tartışılmakta olan bir siyaset teorisidir. Bu siyaset teorisi, büyük oranda Quentin Skinner ve Philip Pettit'nin katkıları ile bugünkü konumuna gelmiştir. Bir düşünce tarihçisi olan Skinner'ın cumhuriyetçiliğe katkısı, cumhuriyetçi geleneğe getirdiği bir yorum üzerinde yükselir (Skinner 1984, 1986, 1990, 1998, 2002 ve 2008). Skinner, özelikle Machiavelli üzerine olan çalışmalarında, onun ve ardıllarının düşüncelerini temele alarak politik özgürlüğe dair yeni bir anlayış geliştirmeye çalışmıştır. Pettit ise, Skinner'ın tarihsel yaklaşımını tamamlayacak bir biçimde, cumhuriyetçi politik özgürlüğü tahakkümsüzlük (non-domination) olarak tanımladığı bir cumhuriyetçi siyaset teorisi geliştirmeye çalışmış ve bu teorinin tutarlı ve bütünsel bir şekle bürünmesi için çabalamıştır (Pettit 1989, 1998, 1999, 2003, 2004, 2005 ve 2011).

Cumhuriyetçiliğin çağdaş siyaset felsefesine en önemli katkısı, onun liberal özgürlük anlayışına getirdiği eleştirilerden ve bu eleştiri üzerinden politik özgürlük kavramına kazandırmaya çalıştığı yeni bir yaklaşımdan oluşur (Tunçel 2010, 10-13). Liberal siyaset teorisinin özgürlük tanımı, 19. yüzyılın sonlarından itibaren siyaset felsefesinde gerçekleştirilen özgürlüğe dair tartışmaları büyük ölçüde belirlemiş ve bu alanda bir hâkimiyet kurmuştur (Haakonssen 1993, 729; Skinner, 1998 96-99; Pettit 1998, 71-79; Honohan 2002, 1-2; Maynor 2003, 1). İşte cumhuriyetçi siyaset teorisi de, kendi felsefi konumunu belirlemek ve özgürlüğe dair yeni bir anlayış geliştirmek istediğinde, hem bu alandaki hâkim görüş olan liberal özgürlük anlayışını eleştirerek, hem de 20. Yüzyılın ortalarından beri politik özgürlüğe dair genel kabul gören ikili bir ayrımı sorgulayarak işe başlar.

Philip Pettit, cumhuriyetçi düşünürler içinde, politik özgürlüğün yeni bir tanımını geliştiren ve bu tanımı sistematik hale getiren kişidir. Pettit politik özgürlüğün, 'tahakkümsüzlük' olarak adlandırdığı kavram ile açıklanması gerektiğini söyler. Ayrıca o ortaya koyduğu teoriyi, özgürlüğü 'müdahalesizlik' (non-interference) olarak anladıklarını söylediği liberallerin iddiaları ile karşılaştırır (Pettit 1998, 67-78, 119-130). Bu karşılaştırmayı yapmadan önce ise, felsefe tarihi içinde politik özgürlüğe dair ortaya atılan düşünceleri iki ayrı grupta toplayan Isaiah Berlin'i eleştirir. Pettit'e göre, Berlin'in ortaya koyduğu ayrım, sahte bir ikililik yarattı̆̆ için terk edilmesi gereken bir ayrımdır. Pettit ile Skinner'ın ardından gelen cumhuriyetçi düşünürler de, kendi düşüncelerini ortaya koyarlarken, liberalizmin özgürlük yaklaşımının özgürlügü açıklamada yetersiz kaldığını farklı şekillerde ifade etmişlerdir. Bu eleştirilerine koşut bir şekilde birçok cumhuriyetçi, Berlin'in negatif özgürlük-pozitif özgürlük ayrımının, cumhuriyetçi geleneğin sahiplendiği özgürlük yaklaşımını yok saymasını eleştirmiş ve bu söz konusu ayrımın, liberal özgürlük anlayışının temel dayanaklarından biri olduğunu belirtmiş̧lerdir.

\section{Negatif Özgürlük-Pozitif Özgürlük Ayrımı}

Isaiah Berlin'in 'İki Özgürlük Kavramı' (Two Concepts of Liberty) adlı makalesi, “20. Yüzyıl içinde politika felsefesine yapılmış en belirleyici katkılardan biridir" (Knowles 2001, 74). Berlin, bugün artık klasikleşmiş bu makalesinde düşünce tarihi içinde politik özgürlüğe dair yapılmış olan tanımların iki ayrı kampta toplanabileceğini belirtir (Berlin 1958, 119-125). Bu iki farklı özgürlük anlayışı, özgürlükle ilgili olarak sorulabilecek iki farklı soruya verilen yanıtlar üzerinde yükselir. Bu sorulardan ilki şudur: Başkalarının müdahalesi olmadan, bir kişinin 
yapmaya gücünün yettiklerini yapabilmesinin sınırı ve alanı nedir? $\mathrm{Bu}$ sorunun yanıtı arandığında, artık negatif özgürlük üzerine konuşuluyor demektir. Fakat eğer 'Bir kişinin eylemlerinin belirlenmesine neden olan kontrolün kaynağı nedir?' sorusuna bir cevap aranıyorsa, bu soruya verilecek cevaplar pozitif özgürlükle ilgili olacaktır.

Pozitif özgürlüğe sahip olmak demek, kişinin kendi benliği üzerinde hâkimiyet kurabilmiş olması, kendini rasyonel bir varlık olarak tanıyarak ve olumlayarak kendi kararlarını alabilmesi ve bu kararların sonuçlarını göğüsleyebilmesi demektir (Berlin 1958, 125). Bu yaklaşıma göre, bir kişi başkaları tarafından harekete geçirilmekten, yani başkaları için bir araç olarak kullanılmaktan korunarak, sadece ve sadece kendi istekleri ve arzuları doğrultusunda eylemde bulunduğunda özgür olur. Pozitif özgürlük, isminden de açıkça anlaşılacağı gibi, insanların özgür olmaları için bir takım niteliklere sahip olmaları gerektiği düşüncesini içinde barındıran bir özgürlük anlayışıdır.

Berlin, pozitif özgürlüğün ilk bakışta oldukça etkileyici bir özgürlük yaklaşımı olarak gözükmesine rağmen, çok önemli riskler ve sıkıntılar içerdiğini belirtir (Berlin 1958, 126-127). Pozitif özgürlük yaklaşımında öncelikle, insanın kontrol eden ve kontrol edilmesi gereken iki parçası olduğu kabul edilerek işe başlanır. İnsanı bağımsız ve kendi benliğinin hâkimi olacak bir konuma ise sadece kontrol eden ya da akılsal yönü ulaştırabilir. Bu nedenle de, arzular ve hazlarla ilgili olan diğer parçamızın akılsal yönümüz tarafından kontrol altına alınması gerekir. Bir siyasal iktidar, rasyonel olanın ne olduğunu bildiğini ve pozitif özgürlük anlayışını göz önüne alarak eylemde bulunduğunu, yani insanları özgürleştirmek istediğini söylediğinde, ortada büyük bir tehlike var demektir. Çünkü böyle bir durumda, insanların eylem olanaklarını sınırlandıran veya kısıtlayan her müdahale, bu müdahalelerin onları özgür kılmak amaciyla yapıldığının söylenmesiyle meşrulaştırılabilir. Bu ise, bir iktidarın toplum içindeki bireylere uyguladığı her türlü müdahaleyi böyle bir söylemle meşrulaştırabileceği anlamına gelir.

Sorun sadece bir siyasal iktidarın her müdahalesini meşrulaştırabilecek olması değil, bu siyasal iktidarın gerçekleştireceği eylemleri, müdahale edilen kişileri özgürleştireceği iddiasını temele alarak yapabilecek olmasıdır. Berlin'e göre, böyle bir iddiayı temele alan meşrulaştırma girişimleri, paternalistik bir söyleme dayanan girişimlerden bile daha tehlikelidir:

Benim, kendisi bilmemesine rağmen $X$ için iyi olanın ne olduğunu bildiğimi söylemem ve kendi iyiliği için onun isteklerini göz ardı etmem bir şey, onun bunu bilinçli bir şekilde olmasa da, günlük yaşamında gözüktüğ̈̈ şekilde değil ama onun empirik yanının bilmeyebileceği rasyonel yanı, yani iyiyi fark eden ve bir kez ortaya çıktı̆̆nda onu seçmekten başka yolu olmayan 'gerçek' yanı gereği, eo ipso seçtiğini söylemem başka bir şeydir (Berlin 1958, 126).

Berlin'e göre pozitif özgürlük, özgürlüğe dair görünüşte oldukça ilgi çekici bir tanım dile getiriyor olmasına rağmen, barındırdığ 1 riskler yüzünden terk edilmesi gereken bir anlayıştır. Savunulması ve bir ideal olarak toplumdaki bireyler nezdinde gerçekleştirilmesi gereken özgürlük negatif özgürlüktür. Negatif özgürlük yaklaşımına göre, kişilerin özgür olması için belirli bazı niteliklere sahip olmaları gerekmez; insanları özgür yapan kendilerine başka insanlar tarafından müdahale edilmemesidir. Berlin bunu şöyle ifade eder:

Benim, normal olarak, hiçbir insanın ya da insan topluluğunun eylemlerime müdahale etmediği ölçüde özgür olduğum söylenir. Bu anlamıyla politik özgürlük, basitçe, bir insanın diğerleri tarafindan engellenmeden eylemlerini gerçekleştirebildiği alandır. Ĕ̆er diğerleri tarafindan 
normalde gerçekleştireceğim eylemleri gerçekleştirmem engellenirse, özgürlükten o derece yoksunum demektir ve bu alan başkaları tarafindan belirli asgari bir düzeyin ötesinde küçültülürse, baskı altına alınmış ve hatta köleleştirilmiş olurum (Berlin 1958, 120).

Negatif özgürlük anlayışında özgürlük, kişinin başka insanların müdahalesine uğramadan kendi istediklerini yapabilmesiyle mümkün olur. Bu anlayışa göre, bir insan ancak ve ancak kendisine başka kişiler tarafından bilinçli hiçbir müdahalede bulunulmaması durumunda mutlak anlamda özgürdür. Böyle bir yaklaşımın, bireysel özgürlükler ile bireysel hakları en önemli değer olarak gören ve bu değerlerin her koşulda korunması gerektiğini savunan liberal siyaset teorisi ile uyum içinde olduğu açıkça görülebilir.

\section{Müdahalesizlik Olarak Özgürlük}

Müdahalesizlik olarak özgürlük, ya da Berlin'in meşhur ayrımını temele alarak söylersek negatif özgürlük, liberal siyaset teorisinin temelinde bulunan politik özgürlük anlayışıdır. "Klasik liberalizm, özgürlüğün negatif kavrayışı üzerine kurulur" (Gaus 2000, 91). Negatif özgürlük anlayışına göre özgürlük, baskının yokluğu ile var olur. Baskı ise, bu yaklaşım içinde, başka kişilerin bir insana bilinçli bir şekilde uyguladığı müdahaleler olarak anlaşılır.

Felsefe tarihi içinde negatif özgürlük yaklaşımını en iyi şekilde savunan filozoflardan biri Thomas Hobbes'tur. O özgürlüğü şöyle tanımlar: “ÖZGÜRLÜK'TEN, kelimenin doğru anlamıyla, dış engellerin yokluğu anlaşı1ır: bu engeller, çoğu zaman, insanın dilediğini yapma gücünün bir bölümünü elinden alabilirler; fakat kendisinde kalan gücü, muhakeme ve aklının emrettiği şekilde kullanmaktan onu alıkoyamazlar" (Hobbes 2008, 96). Bir materyalist olan Hobbes için, bir kişinin istediklerini yapmasını engelleyen her türlü kısıtlama fiziksel bir kısıtlamadır. Öyle ki, bu düşünceye göre bir insanın özgürlüğünün azalmasının tek yolu onun bir eylemi gerçekleştirmesinin imkânsız hale gelmesidir. Örneğin Hobbesçu bakış açısına göre, birinin yolunu kesen ve ona 'Ya paranı ya canını' diyen bir soyguncu bu kişinin özgürlügünü azaltmayacaktır (Carter 2008, 62). Burada bu kişinin hem parasını hem de canını koruma seçeneğinin bedelinin oldukça ağırlaşmasından bahsedebiliriz. Fakat bu kişi parasını vermeyerek canından olmak ile parasını verip hayatını kurtarmak seçeneklerine hala sahiptir. Hobbes için, onun böyle bir seçim olanağına sahip olması, yani fiziksel bir imkânsızlık içinde bulunmaması, bu kişinin özgür olması için yeterlidir.

Hobbes'un özgürlük anlayışı, negatif özgürlüğün en doğrudan ve en net tanımlarından birini içerir. Fakat netliği sayesinde bu yaklaşım bize negatif özgürlüğün temel özelliklerini anlamak konusunda yardımcı oluyor olsa da, onun felsefi anlamda naif ve çağdaş siyaset felsefesi standartlarında oldukça arkaik bir yaklaşım olduğunu belirtmek gerekir.

Negatif özgürlük anlayışının çağdaş liberal siyaset teorisi üzerindeki etkisini en iyi gösteren özgürlük tanımlarından biri John Stuart Mill tarafından yapılmıştır. Mill özgürlüğün ne demek olduğunu şöyle açıklar: "Özgürlük demeye layık biricik özgürlük başkalarını mutluluklarından yoksun bırakmaya ya da onların mutluluğa ulaşma çabalarına engel olmaya kalkışmadığımız sürece, kendi iyiliğimizi kendi bildiğimiz yolda aramak özgürlüğüdür” (Mill 2014, 27). Bu kısa ve öz tanım içinde hem negatif özgürlüğe dair klasik bir yaklaşım ortaya konmakta, hem de bireysel iyilerin önemi vurgulanmaktadır. İnsanların kendi iyilerini kendi istedikleri biçimlerde elde etmeye çalışmaları onların özgür olduklarını gösterir. Bireysel iyiye yapılan bu vurgu, Mill'in özgürlüğe dair düşüncelerini büyük oranda sahiplenen çağdaş liberalizm içinde de önemli bir yer kaplamaktadır.

Mill'in tanımında insanların özgür olmaları, istedikleri gibi yaşamaları anlamına gelir. Ama 
bu şekilde yaşamayı sınırlandıran bir koşul vardır; bu koşul ise insanların kendileri dışındakilerin özgürlüğünü kısıtlamamaları gerekliliğidir. Böyle bir kısıtlama, diğer kişilerin bireysel iyilerinin peşinden koşmalarının engellenmesi, yani onlara müdahale edilmesi sonucunda ortaya çıkar.

Negatif özgürlük yaklaşımı ve bu yaklaşım üzerine inşa edilen liberalizm, yaklaşık son yüz elli yıldır, siyaset felsefesi içindeki bütün tartışmalara bir şekilde dâhil olmakta ve çağdaş politika felsefesini önemli ölçüde etkilemektedir. Bu nedenle de, Berlin'in ikili ayrımına karşı çıkan ve özgün bir teori geliştirmeye çalışan cumhuriyetçiler, bu uğraşları boyunca pozitif özgürlük-negatif özgürlük ayrımı kadar negatif özgürlük anlayışının kendisini de eleştirmişler ve kendi iddialarını liberal özgürlük anlayışına getirdikleri itirazlar üzerinden temellendirmeye çalışmışlardır.

\section{3. Özgürlüğe Dair Üçüncü Bir Yaklaşım: Tahakkümsüzlük Olarak Özgürlük}

Cumhuriyetçiler, özgürlüğe dair yeni bir yaklaşım geliştirmeye çalışırlarken, ilk olarak Berlin'in negatif özgürlük-pozitif özgürlük ayrımını eleştirmiş ve böyle bir ayrımın temele alınmasının özgürlügün anlaşılması konusunda problemler yaratacağını iddia etmişlerdir (Maynor 2003, 1620; Pettit 1998, 37-43; Skinner 2002, 237-243; Tunçel 2010, 260-261). Cumhuriyetçilere göre, ortaya konduğu andan itibaren politik özgürlük üzerine yapılan tartışmaların çerçevesini belirlemiş olan negatif özgürlük-pozitif özgürlük ayrımı, her şeyden önce, yarattığı ikililiğin yanlış olması nedeniyle reddedilmelidir. Bu ayrım ve bu ayrıma dayanan özgürlük anlayışı, hem çağdaş politik sorunlara yanıt bulmakta bize yardımcı olamamakta, hem de çağdaş politika felsefesi içinde oldukça yetersiz kalmaktadır (Maynor 2003, 19; Pettit 1999, 164-165). Düşünce tarihi içinde ortaya konmuş olan özgürlük yaklaşımlarının iki kampta toplanabileceğini söylemek, aynı zamanda, politik özgürlüğe dair üçüncü bir yaklaşımın var olmadığını söylemek anlamına gelir.

Cumhuriyetçi teori içinde özgürlüğe dair yeni olma iddiasındaki bir yaklaşım Quentin Skinner ve Philip Pettit tarafindan geliştirilmiştir. Pettit ve Skinner, cumhuriyetçi özgürlük ya da tahakkümsüzlük olarak özgürlük olarak adlandırdıkları bu özgürlük anlayışının, Berlin tarafından ortaya konan ayrıma bir alternatif olduğunu söylerler (Pettit 1998, 43-49; Skinner 2002, 261-265). Onlara göre, geliştirdikleri özgürlük anlayışı özgün olmakla beraber, politik düşünce tarihi içinde belirli dayanaklara sahiptir. Klasik cumhuriyetçi gelenek içinde özgürlük, her zaman tahakkümsüzlük olarak anlaşılmıştır.

Pettit, tahakkümsüzlük olarak anlaş1lan cumhuriyetçi politik özgürlüğü temellendirmeye ve açıklamaya çalışırken, onu sık sık liberal politik özgürlük anlayışıyla karşılaştııır ve iki yaklaşım arasındaki farkları göstermeye çalışır. Ona göre cumhuriyetçi özgürlük, negatif özgürlüğün farklı bir yorumu değil, hem negatif özgürlük hem de pozitif özgürlük ile belirli ortaklıklar taşıyan bir yaklaşımdır.

Pettit'e göre, tahakkümsüzlük olarak özgürlük ya da cumhuriyetçi özgürlük, negatif özgürlükle de pozitif özgürlükle de ortaklıklar taşıdığı için hem bu iki anlayışın bir sentezidir, hem de onlar karşısında bir alternatif teşkil eder (Pettit 1999, 164). Cumhuriyetçi özgürlük, tahakkümün yokluğunu özgürlük olarak tanımlar. Bu nedenle de o, özgürlüğü bir etkinin -müdahaleninyokluğu olarak anlayan negatif özgürlüğe benzer. Fakat cumhuriyetçi özgürlük, negatif özgürlükten farklı olarak, müdahalenin yokluğunu değil tahakkümün yokluğunu, yani bir kişinin başka bir kişi üzerinde sahip olabileceği mutlak karar verme gücünün yokluğunu özgürlük olarak görür. Cumhuriyetçi özgürlüğün böyle bir müdahale etme gücüne bakış1 ise, onu pozitif özgürlüğe benzetir. Çünkü bir insan, ancak ve ancak belirli niteliklere sahipse, potansiyel bir 
tahakküm ilişkisinden, yani başkalarına bağımlı olma tehlikesinden kurtulabilir. Yani bir insanın özgür olması, onun başkalarına bağımlı olmaması anlamında kendisinin hâkimi olması demektir. Pettit, cumhuriyetçi özgürlük anlayışının, Berlin'in ortaya koyduğu ve ortaya konduğu zamandan beri genel kabul gören negatif özgürlük-pozitif özgürlük karşıtlığını aşabileceğini belirtir:

Bu ihtimal negatif özgürlükle ortak bir kavramsal öğeye -mevcudiyete değil, yokluğa odaklanmaya- ve pozitif kavrayışla ortak bir öğeye müdahaleye değil kendi benliği üzerinde hâkimiyete odaklanmaya- sahip olacaktır (Pettit 1998, 43).

Negatif özgürlük yaklaşımının özgürlüğü müdahalesizlik olarak anlamasına karşı çıkan ve tahakkümsüzlügün özgürlük olarak anlaşılması gerektiğini söyleyen cumhuriyetçi siyaset teorisinin bu iddiasını daha iyi anlamak için ise tahakkümün ne olduğuna bakmak gerekir.

\subsection{Tahakkümün Üç Temel Unsuru}

Tahakküm, bir kişi ya da grubun başka bir kişi ya da grup üzerinde keyfi temelde müdahale etme gücüne sahip olduğu bir ilişki biçimidir. Bu ilişki, her zaman belirli kişiler ya da gruplar arasında var olur; yani o toplumsal bir ilişki biçimidir ve bu ilişki en iyi şekilde 'efendi ile köle ya da efendi ile hizmetkâr arasındaki ilişkide ifade bulur" (Pettit 1998, 44). Tahakkümün bu tanımında açık kılınması gereken üç nokta bulunmaktadır. Öncelikle bir eylem olarak müdahale etmenin neleri kapsayıp kapsamadığının net olarak açıklanması, ikinci olarak keyfi bir temelde müdahalede bulunmanın nasıl bir müdahale şekli olduğunun belirtilmesi ve son olarak da, fiili bir müdahalede bulunma ile fiili bir müdahalede bulunma gücüne sahip olma arasındaki farkların neler olduğunun gösterilmesi gerekir. Bu üç noktanın, yani tahakkümün üç temel unsurunun incelenmesi, tahakkümün ne olduğunun anlaşılmasına katkı sağlayacaktır.

Müdahalenin özellikleri nelerdir? Müdahalenin ilk özelliği, onun, müdahale edilenin mevcut durumunu kötüleştiren koşullar yaratan bir eylem biçimi olmasıdır (Pettit 1996, 566-567; 1997, 81). Bir kişinin mevut durumunun kötüleşmesi ise, kendisine yapılan müdahale sonucunda bu kişinin eylem olanaklarının ya daralmasına ya da kendi yararı için yapacağı seçimlerin daha zor tercih edilebilir hale gelmesine yol açan koşulların oluşması demektir. Burada dikkat edilmesi gereken nokta, insanların mevcut durumlarını kötüleştiren koşullar yaratan bir müdahalenin, cumhuriyetçilere göre, ahlaki açıdan 'kötü' bir eylem olması gerekmediğidir (Pettit 1998, 83). Yani ahlaki olarak meşrulaştırılabilen bir müdahale, etkilediği kişilerin mevcut durumlarını oldukça kötüleştirebilir. Fakat müdahale edilen bir kişinin mevcut durumunun kötüleşmesi ve bu kötüleşmenin derecesi, her zaman içinde bulunulan koşullara bağlıdır. Böyle bir değerlendirme yapabilmek için sabit ve değişmez bir kriter belirlemek mümkün değildir.

Müdahale edenin bilinçli olarak ve isteyerek gerçekleştirdiği bir eylem olarak müdahale, müdahale edilenin mevcut durumunu üç şekilde kötüleştirebilir; bunlar fiziksel bir engel olarak bedenen kısitlama, ceza veya ceza tehdidi olarak iradi kısıtlama ve manipülasyondur (Pettit 1998, 81; Costa 2007, 292-293). Örneğin bir insanın tek bir çıkışı olan bir odada bulunduğunu düşünelim. Eğer odanın kapısını dışarıdan kilitleyip bu insanın odadan çıkışını fiziksel olarak engellersek, bu kişiyi bedenen kısıtlayan bir müdahalede bulunmuş oluruz. Bu durumda biz, bu insanın eylem seçeneklerinden birisini -odadan çıkmak- imkânsız hale getiririz. Odanın kapısını kilitlemediğimiz, fakat bu söz konusu kişiye odadan çıktığı anda yaptırım uygulayacağımızı söylediğimiz zaman ise müdahalemiz, ceza tehdidine dayalı iradi bir kısıtlama halini alır. Böyle bir müdahale odadaki insanın eylem seçeneklerinden birinin daha zor tercih edilebilir hale gelmesine yol açar. Aynı insanı, kendi çıkarlarının aleyhine olmasına ve bizim çıkarımız lehine bu odada kalmaya herhangi bir şekilde ikna ettiğimizde, bu kişiye manipülasyon ile müdahale 
etmiş oluruz. Bu durumda da kişinin normalde tercih etmeyeceği bir eylemi gerçekleştirmesi, bu söz konusu eylemi kendi isteğiyle gerçekleştirmiş olsa da, bu insanın mevcut durumunu kötüleştirir.

Müdahalenin ikinci özelliği, onun bilinçli bir şekilde gerçekleştirilen bir eylem biçimi olmasıdır. Müdahalede bulunan fail bu söz konusu müdahaleyi, eyleminin bir müdahale olduğunu bilerek gerçekleştirir. Bu yüzden de, insanların seçim olanaklarını daraltan ya da bazı seçimlerinin daha zor tercih edilebilir hale gelmesine yol açan, fakat bilinçli bir fail tarafindan oluşturulmamış koşulların herhangi bir müdahale ile oluştuğunu söylemek mümkün değildir. Örneğin çeşitli doğa olayları, insanların hayatına ne kadar kötü etkilerde bulunursa bulunsun, müdahale sayılamaz. Ya da bir insanın kazara gerçekleştirdiği bir eylem, başka bir insana zarar vermiş olsa bile, müdahale olarak adlandırılamaz.

Müdahalenin ne olduğunun ve neleri kapsayıp kapsamadığının açıklanmasından sonra, gösterilmesi gereken, keyfi temelde müdahalenin (interference on an arbitrary basis) ne türden bir müdahale olduğudur. Keyfi temelde bir müdahalenin, birisi müdahale eden ile ilgili, diğeri müdahale edilen ile ilgili olmak üzere iki temel özelliği vardır. Müdahaleyi uygulayan kişiye, o bu söz konusu müdahaleyi gerçekleştirirken, herhangi bir karşı çıkış mümkün değilse ve bu kişinin, gerçekleştireceği müdahale sonucunda herhangi bir yaptırımla karşılaşma riski yoksa bu kişinin gerçekleştireceği müdahaleler keyfi bir temele sahip olur (Pettit 1998, 84-85). Müdahalede bulunma imkânına sahip olan kişinin eylemlerinin, kurumsal ve idari yapı içinde herhangi bir şekilde engellenemediği böyle bir durumda ise, keyfi temelde müdahalelerin gerçekleştirilip gerçekleştirilmemesi, tamamen, müdahale etme imkânına sahip olan kişinin kendi isteğine ve arzusuna bağlıdır (Lovett 2012, 139). Bu güce sahip olan kişi, keyfi bir temelde, istediği an ve istediği şekilde müdahalede bulunma şansına sahiptir. Keyfi temelde müdahalenin müdahale edilen ile ilgili olan özelliği ise onun, kendisine müdahale edilen kişinin düşüncelerini ve çıkarlarını hiçbir zaman göz önüne almamasıdır (Pettit 1998, 85). Yani keyfi temelde yapılan müdahaleler, ister müdahale edenin çıkarına ister tahakküm ilişkisinin doğrudan içinde olmayan kişilerin çıkarına olsun, kendilerine müdahale edilen insanların fikirlerini önemsemez ve çıkarlarını gözetmez. Bu anlayışa göre, politik bir iktidarın keyfi temelde müdahaleleri ise toplumun ortak iyisine aykırı olan müdahalelerdir. Cumhuriyetçiler için ortak iyi kavramı, onların tahakkümsüzlük olarak özgürlük yaklaşımlarında önemli bir yer kaplar.

Bir iyi hangi koşullarda ortak bir iyi olur? Pettit'e $(1998,165)$ göre, eğer bir iyi toplumdaki diğer kişiler için arttırılmadıkça herhangi bir kişi için de arttırılamıyorsa, o ortak bir iyidir. Yani ortak iyi, toplumda ya herkes için arttırılacaktır ya da hiç kimse bu iyiye sahip olamayacaktır. Tersten söylersek, toplum içindeki bir kişi bile bu iyiye sahipse, eğer bu iyi ortak bir iyiyse, diğer bütün insanlar da bu iyiye sahip demektir. Ortak iyi, toplum içindeki bireylerin beyan edebildikleri her türlü kişisel çıkardan değil, onların yurttaş olarak ortak çıkarlarından oluşur (Pettit 2004, 158-159). Pettit (1998, 165), tartışmasız olarak ortak olduğu kabul edilen iyilere örnek olarak temiz hava ve dış savunmayı verir.

Keyfi temelde müdahalenin yukarıda bahsettiğim iki özelliği dikkate alındığında, bir eylemin keyfi bir temele dayanmasını sağlayanın, bu söz konusu müdahalenin sonuçlarıyla değil müdahaleyi sağlayan araçlarla ilgili olduğu görülür. Keyfi bir temele sahip olmayan müdahaleler de belirli bir ahlaki perspektiften bakıldığında kötü olarak değerlendirilebilir veya müdahaleye uğrayan kişilerin mevcut durumlarını oldukça kötüleştirebilirler. Ama böyle bir sonuç, bu müdahaleyi keyfi yapmaz. Bir müdahalenin keyfi olmasını, müdahaleyi yapanın mutlak güce sahip olması ve müdahaleye uğrayanın mutlak güçsüzlüğü ve bağımlılığı belirler. Bir 
müdahalenin, istenilen her an gerçekleştirilebilir olması ve bu müdahaleye herhangi bir karşı çıkışın mümkün olmaması, onun keyfi bir temele sahip olmasının nedenidir.

Eğer gerçekleştirilen her müdahale insanların mevcut durumunu kötüleştiriyorsa, müdahale edilenlerin düşüncelerini ve çıkarlarını göz önüne alan müdahaleler, yani keyfi olmayan müdahaleler nasıl mümkün olur? Bir kişi, mevcut durumunun kötüleşmesinin kendisi açısından istenilebilir olmadığını ve çıkarlarının her zaman böyle bir değişimle çatışacağını düşünmez mi? Tam da bu noktada, cumhuriyetçi politik özgürlük yaklaşımı için kilit önemde olan bir ayrımdan bahsetmek gerekir. Kişilerin mevcut durumlarını kötüleştiren fakat müdahale olarak adlandırılamayacak etkenler, cumhuriyetçi teoriye göre, insanların özgürlüklerinden taviz vermelerine (compromising) yol açmaz; sadece bu özgürlüğü koşullar (conditioning) (Pettit 1998, 109). Doğa olaylarını örnek olarak verebileceğimiz böyle etkenlerin sonucunda insanların özgürlüklerinden taviz verdiklerini söylemek mümkün değildir. Böyle bir durumda insanların özgürlükleri koşullanmış olur. Özgürlüklerinin koşullanması ile de, insanların seçim olasılıkları daralır; yani sınırsız bir serbestlik içinde eylemde bulunma şansları ortadan kalkar. Özgürlüksüz kalan (nonfree) kişi, özgürlüğü koşullanan biridir; özgürlükten uzaklaşan (unfree) bir kişi ise özgürlügünden taviz vermiş demektir (Türkçede 'nonfree' ve 'unfree' kavramlarına farklı karşılıklar da bulunabilir. Cumhuriyetçilik kitabının Türkçe çevirisinde yer alan 'özgürlüksüz kalan’ ve ‘özgürlükten uzaklaşan' ifadeleri, gündelik dilde kullanılmadıkları ve Türkçenin dil yapısına tam olarak uymadıkları için anlaşılmada çeşitli sıkıntılar yaratabilir. Fakat ben, konuyla ilgili Türkçe literatürde tutarlılık olması açısından söz konusu ifadeleri değiştirmeden birakıyorum).

Özgürlükten taviz verilmesi ile özgürlüğün koşullanması ayrımı dikkate alındığında, cumhuriyetçilerin kendi özgürlük yaklaşımlarının müdahaleye dair düşünceleri bakımından liberal özgürlük yaklaşımından farklı olduğu iddiası şöyle aktarılabilir: Liberalizmde, amacından ve uygulanış biçiminden bağımsız olarak her türlü müdahale özgürlükten taviz verilmesine yol açar. Cumhuriyetçilerin yaklaşımına göre ise, yalnızca keyfi bir temelde gerçekleştirilen müdahalelerin böyle bir sonucu olur; keyfi olmayan müdahalelerse özgürlügü yalnızca koşullar (Pettit 1998, 110). Yani müdahale edilen insanların düşüncelerini ve çıkarlarını göz önüne alan müdahaleler, bu söz konusu kişilerin özgürlüğünü koşullayan eylemlerdir.

Keyfi olmayan müdahalelerin nasıl mümkün olduğu sorusuna dönülecek olursa, bu sorunun birbiriyle bağlantılı ve birbirini tamamlayan iki cevabı olduğu söylenebilir. İlk olarak, gerçekleştirilen bir müdahalenin müdahale edilen insanların çıkarlarıyla uyuşması düşüncesi, bu insanların bir toplum içinde yaşadıklarını göz önüne aldığımızda mümkün hale gelir. Bir toplum içinde yaşayan her bireyin bütün isteklerinin tatmin edilmesi, ne teoride ne de pratikte mümkün değildir. $\mathrm{Bu}$ nedenle, bu insanlara yapılan bir müdahalenin keyfi olmaması için, bütün bu insanların ortak iyisinin göz önünde bulundurulması gerekir. Toplumdaki bütün bireylerin ortak iyisi için yapılan bir müdahale, bu toplum içindeki bireylerin özgürlügünü koşullamakla birlikte özgürlükten taviz verilmesine yol açmaz.

Bir müdahalenin, müdahale edilen kişilerin düşünceleri göz ardı edilmeden gerçekleştirilmesi ise, onların ortak çıkarlarını, bireysel çıkarlarından daha fazla önemsemeleri ve bu söz konusu ortak çıkarın gerçekleştirilmesinin onlar için daha faydalı olmasıyla ilgilidir. Toplumsal yaşam içinde insanlara getirilen sınırlamaların birçoğu, bu sınırlamaların olmadığ bir yaşamda ortaya çıkması oldukça olası olan potansiyel tehlikelerin vereceği zararları engeller. İnsanların eylem olanaklarını azaltma anlamındaki mevcut durumlarının kötüleşmesi durumu, daha genel bir çerçeveden bakıldığında onların yaşam kalitesini arttırır. Cumhuriyetçilere göre, liberal teorinin özgürlüğe yaklaşımı açısından bu, özgürlüğün toplamda arttırılması için belirli 
alanlarda azaltılması, yani bireylerin özgürlügünü daha az azaltan uygulamaların tercih edilmesi demektir. Cumhuriyetçi politik özgürlük yaklaşımına göre ise, toplumdaki bireylerin özgürlüklerini koşullayan müdahaleler, bu bireylerin özgürlüklerinden taviz vermemelerini sağlar. Yani ortak iyiyi gözeten müdahaleler, toplumdaki kişiler arasında tahakküm ilişkilerinin kurulmamasını garanti altına alır (Pettit 2005, 92-100; Skinner 2008, 96). Böylece, insanların toplumdaki diğer kişilerle birlikte sahip oldukları ortak iyinin gerçekleştirilmeye çalışılmasının, kendi mevcut durumlarının iyileşmesi için önemli bir araç olduğu göz önüne alındığında, bireylerin ortak iyisini gözeten her müdahalenin, onların istekleri ve düşünceleriyle de uyum içinde olduğu sonucuna ulaşılır.

Fakat bir müdahalenin keyfi bir temele dayanıp dayanmadığı, yalnızca, müdahale edilen kişilerin bu söz konusu müdahaleyi onaylayıp onaylamamalarına bakılıp değerlendirilemez. Çünkü manipülasyon da bir müdahale biçimidir ve dolayısıyla keyfi temelde manipülatif müdahalelerin gerçekleştirilmesi de mümkündür. Yani müdahale edilenlerin anlık ya da periyodik onayları, bir tahakküm ilişkisini ortadan kaldırmaya yetmez. Bu nedenle cumhuriyetçiler keyfi temelde müdahalelerin engellenmesi için farklı bir şart daha öne sürerler. Bu şart şudur: Müdahaleye uğrayanların özgürlüklerini sınırlandıran herhangi bir uygulama, kararın alınmasından çok sonra bile, gerekli görüldüğü anda müdahale edilenler tarafından kaldırılabilmelidir. Bu her koşulda mümkün olmasa bile, en azından bu kişilerin karara itiraz etme güçleri olmalıdır (Pettit 1998, 92-94). Bu durumu en iyi, devlet ile yurttaşlar arasındaki ilişkide görürüz: Bir devletin uygulamalarının keyfi olup olmadığını anlamak için, bütün yurttaşların düzenli olarak bu uygulamaları onaylayıp onaylamamasına bakmak yeterli değildir. Ama eğer bu devletin yurttaşları herhangi bir kararı uygun bulmadıklarında bu karara itiraz etme gücüne sahiplerse, kendilerine yapılan müdahalelerin keyfi bir temele dayanmadığı söylenebilir.

Tahakkümün üçüncü temel unsuru, onun, keyfi temelde bir müdahalenin yalnızca fiili olarak gerçekleştirilmesi sonucu var olan bir ilişki biçimi olmamasıdır. Tahakküm ilişkisini mümkün kılan durum, böyle bir müdahalenin her an gerçekleştirilme ihtimalinin varlığı, yani bir kişi ya da grubun başka bir kişi ya da grup üzerinde keyfi bir müdahale gerçekleştirme gücüne ve imkânına sahip olmasıdır (Pettit 1998, 80-81). Herhangi toplumsal bir ilişkideki taraflardan birinin böyle bir güce sahip olmasının nasıl sonuçlara yol açabileceğine dair en iyi örnek, cumhuriyetçi gelenekte de sıklıkla kullanılmış olan efendi-köle örneğidir (Lovett 2014). Bir köle, efendisinin iyi karakteri nedeniyle ya da kendisinin kurnazlığ 1 ve efendisinin isteklerini uygun bir şekilde yerine getirebilmesi sayesinde, müdahaleden belki de tamamen uzak yaşayabilir. Ama bu durum, onun özgür bir insan olduğu anlamına gelmez. İçinde bulunduğu tahakküm ilişkisindeki bağımlı konumu değişmediği sürece, o bir köle olarak kalmaya devam edecektir. Tahakküm ilişkisini belirleyen, fiili olarak gerçekleştirilmiş olan keyfi bir müdahalenin varlı̆̆ değil, böyle bir müdahalenin her an gerçekleşebilmesi ihtimalinin varlığıdır. Müdahalenin kendisi değil onun uygulanabilme kapasitesi, yani müdahale etme gücüne sahip olan kişinin tam da bu güce sahip olması, tahakküm ilişkisinin varlık nedenidir.

\subsection{Tahakkümün Özellikleri}

Tahakkümün ne olduğunun netleştirilmesinin ardından yapılması gereken, tahakkümün söz konusu tanımından hareketle ortaya konabilecek çeşitli özelliklerini açık kılmaktır. Bir tahakküm ilişkisindeki tarafların, bu söz konusu ilişkideki konumlarını biliyor olması, tahakkümün en temel özelliklerinden biridir. Bir tahakküm ilişkisinde, hem tahakküm kuran hem de tahakküm altında bulunan, bu asimetrik yapıda sahip oldukları gücün ya da güç eksikliğinin bilincindedirler (Pettit 1998, 89). Tam da bulundukları konum ve bu konum gereği yapabilecekleri ve yapamayacakları ile ilgili olan bu bilgi, tahakküm altında bulunanın, bir kendini sınırlandırma 
mekanizması sonucunda, özgürlügünden taviz vermesine yol açar.

Fakat böyle bir bilgiye, sadece ilişkinin tarafları sahip değildir; bu ilişkiyle dolaylı bağlantı kuran birçok kişi de bu bilgiyi elde etmiş durumdadır (Pettit 1998, 91). Toplum içinde var olan bir tahakküm ilişkisi ne kadar çok insanı kapsarsa, onun toplumdaki görünürlüğü de o kadar artar. Görünürlüğün artması ise, bu ilişkinin bilgisine sahip olan insanların sayısının artması demektir. Fakat bir tahakküm ilişkisinin, tarafları ve bu ilişkiyle dolaylı bağlantısı olanlar tarafından bilinmesi, onun toplum nezdinde ne ise tam da o olarak anlaşılmasını sağlamaz. Bir kişinin gücünün ya da güçsüzlügünün toplum tarafından bilinmesi farklı, bu söz konusu kişinin içinde bulunduğu ilişkinin bir tahakküm ilişkisi olduğunun bilinmesi ise daha farklı bir durumdur. Üzerinde tahakküm kurulan kişinin, kendi konumunu net olarak ifade edemediği durumlarda tahakküm ilişkisi tam anlamıyla görünür olamaz.

Tahakkümün ikinci özelliği, onun her zaman toplumsal temeli olan bir ilişki biçimi olmasıdır (Skinner 1998, 25-27). Birçok tahakküm ilişkisi, iki farklı sosyal grubun bütün üyelerini kapsayacak şekilde var olur. Fakat daha az insanın dahil olduğu tahakküm ilişkilerinde ve hatta tahakküm kuran ve üzerinde tahakküm kurulanın sadece birer kişi olduğu durumlarda bile, onların tam da bulundukları konumlarda bulunmalarını belirleyen koşullar, toplumsal koşullardır. Bir kişi, herhangi bir tahakküm ilişkisi içinde sadece bir birey olarak var olsa bile, onun bu ilişkideki konumu içinde bulunduğu sosyal grup tarafından belirlenir. Sosyal grupların yapıları ve özellikleri tahakküm ilişkilerinin hem nedeni olurlar, hem de bu ilişkilerin sürekliliğini sağlayan koşulları yaratırlar.

Tahakkümün üçüncü özelliği, keyfi temelde yapılan bir müdahalenin yoğunluğunun ve kapsamının her zaman değişiklik göstermesiyle ilgilidir. Keyfi temelde müdahalede bulunma gücü olarak tahakküm, tahakküm altında olanların eylem seçeneklerinin tamamını etkilemediği gibi, onun etkilediği alanlarda oluşturduğu zararın yoğunluğu da değişiklik gösterir (Pettit 1998, 143-148). Keyfi müdahaleler, etkide bulundukları kişilerin yaşamlarının sadece bazı alanlarını etkilerler. Hayatını sürdürdüğü alanlardan birinde tahakküm altında olan bir kişi, başka bir alanda böyle bir tahakkümden uzak olabilir. Benzer şekilde, belirli bir alanda tahakküm altında olan bir kişiye uygulanan keyfi müdahaleler her zaman farklı yoğunluklarda gerçekleşir. Bu kişiye uygulanan keyfi müdahaleler ne kadar yoğunsa, onun özgürlüğü niteliksel bakımdan o kadar azalmış demektir. Bu nedenle de, Pettit'e $(1998,88)$ göre:

Bu yayılım çeşitlilĭği, tahakküm daha çok değil daha az alanda
gerçekleştiği müddetçe önemli olacaktır. Ama ayrıca, belli alanlardaki
tahakkümün başka alanlardakinden daha yıkıcı kabul edildiği, buna
bağlı olarak da örneğin daha merkezi etkinlikler yerine daha tali etkin-
liklerde tahakküm altına girmek yeğlendiği müddetçe, yayllım önem
taşıyacaktır.

Bir kişi ya da grubun başka bir kişi ya da grup üzerinde keyfi temelde müdahale etme gücüne sahip olduğu bir ilişki biçimi olarak tahakküm, toplumsal yapıdan kaynaklanan ve taraflarının kendisinin bilincinde oldukları asimetrik bir güç ilişkisidir. Ayrıca onun, tahakküm altında bulunan kişilere olan etkisi mutlak olarak ölçülemez; keyfi müdahalelerin kapsamı ve yoğunluğu ilişkiden ilişkiye ve farklı zamanlarda değişiklik gösterebilir.

\subsection{Tahakkümsüz Müdahale ve Müdahalesiz Tahakküm}

Tahakkümün ve temel özelliklerinin böyle anlaşılması, özgürlük için tehlike arz edenin müdahale değil tahakküm olduğunu da açık kılar. Bu ise cumhuriyetçilerin, liberal teorinin özgürlüğe yaklaşımı açısından anlamlı olmayan iki kategori hakkında konuşma imkânına sahip 
olmalarını sağlar. Bunlar tahakkümsüz müdahale (interference without domination) ve müdahalesiz tahakkümdür (domination without interference). Keyfi temele dayanmayan müdahalelerin tahakküm ilişkisi yaratmaması tahakkümsüz müdahaleleri olanaklı hale getirir. Keyfi müdahalelerin sadece fiili olarak var olmasının dışında, böyle müdahaleleri gerçekleştirme gücüne sahip olunmasının da tahakkümü oluşturan bir etken olması ise müdahalesiz tahakkümü mümkün kılar. Cumhuriyetçi politik özgürlük anlayışına göre, ilki müdahalenin uygulandığ1 insanların çıkarlarını ve düşüncelerini göz ardı etmediği için bu kişilerin yalnızca özgürlüğünü koşullarken, ikincisi insanların özgürlüklerinden taviz vermelerine yol açar.

Cumhuriyetçilik, negatif özgürlük taraftarlarının özgürlüğün sadece müdahalesizlik ile var olabileceği düşüncesini reddeder. Özgürlüğün tahakkümsüzlük olduğu söylendiğinde ise, müdahalesiz tahakküm ve tahakkümsüz müdahale birer kategori olarak mümkün hale gelir:

Tahakküm, müdahalesiz olabilir çünkü sadece birinin işlerinize keyfi olarak müdahale edebilecek kapasiteye sahip olmasını gerektirir; hiç kimsenin fiili olarak müdahale etmesini gerekli kılmaz. Müdahale tahakküm olmaksızın olabilir çünkü müdahale bir keyfi müdahale kapasitesinin kullanılmasıyla değil, çok daha sınırlanmış bir yetinin kullanılmastyla ilgilidir (Pettit 1998, 45).

Cumhuriyetçi politik özgürlük yaklaşımına göre her türlü müdahale özgürlükten taviz verilmesine yol açmaz. Müdahale edilenin çıkarları ve düşünceleriyle uyumlu olan ve bu kişinin, söz konusu müdahalelerin kendi çıkarlarına uygun olmadığını düşündüğü anda onlara karşı çıkma hakkının olduğu bir ilişkide gerçekleştirilen müdahaleler, keyfi temelde değillerdir. Keyfi bir temelde uygulanmayan müdahaleler ise müdahale ettikleri kişilerin özgürlüklerini sadece koşullarlar.

Fakat özgürlüğü koşullanan bir kişinin de eylem seçenekleri, özgürlüğünden taviz veren bir başkasınınki kadar daralabilir. Hatta bazı koşullarda, özgürlüğün koşullanması, taviz verilmesine kıyasla daha çok seçeneğin tercih edilebilir olmaktan çıkmasına yol açabilir. Ama burada dikkat edilmesi gereken nokta, söz konusu olan azalma ya da artmanın niceliksel bir değişimi ifade ettiğidir. Eylem seçeneklerinin niceliksel artış1 ise, Pettit'e (2008, 104-109) göre, cumhuriyetçi özgürlük yaklaşımının değil liberal özgürlük yaklaşımının temel hedefidir. $\mathrm{Bu}$ görüşe göre, liberal özgürlük anlayış1 için önemli olan, fiili müdahalelerin mümkün olduğunca azaltılması ve insanların eylem olanaklarının mümkün olduğunca arttırılmasıdır. Bu nedenle de, liberal özgürlük düşüncesine göre, her türlü müdahale özgürlükten taviz verilmesine yol açan koşullar yaratır.

Cumhuriyetçiliğin iddiası ise, insanların eylem seçeneklerinin daha çok daraldığı durumlarda bile, özgürlügün koşullanmasının özgürlükten taviz verilmesine tercih edilmesi gerektiğidir. Çünkü cumhuriyetçi özgürlük yaklaşımı için önemli olan, eylem olanaklarındaki niteliksel artıştır (Pettit 1998, 47). Bu düşünceye göre, eylem olanaklarının niteliksel artışı, kişilerin tahakküm ilişkilerinin dışında ve kimseye bağımlı olmadan yapabilecekleri potansiyel seçimlerin artması demektir. Böyle bir durumda kişilerin eylem seçenekleri, başkaları üzerinde tahakküm kurmaya izin vermeyecek şekilde daraltılır. Ama tam da bu daraltılma sayesinde, aynı kişiler, başkalarının kendi üzerlerinde tahakküm kurma ihtimalinin olmadığı koşullarda hareket edebilirler. Bu koşullar içinde yapılması muhtemel seçimler niceliksel olarak oldukça azaltılmış bile olsa, cumhuriyetçilere göre, özgürce yapılmış seçimler olurlar. Ayrıca bu koşullarda yaşayan insanlar, seçim olanakları daraltılmamış fakat her an kendilerine karşı keyfi müdahale gerçekleştirilme riski olan, yani tahakküm altında yaşayan insanlara göre daha özgürdürler. 
Yani tahakküm ilişkisi yaratmayan müdahaleler, insanların özgürlügünü arttırmak için gerçekleştirilen müdahalelerdir. Bu anlamda siyasal iktidarın, bir toplumun bireylerine uyguladığ müdahalelerin keyfi olmama imkânı vardır. Eğer bu iktidar toplumun tamamının yararına, örneğin insanlar arasındaki tahakküm ilişkilerinin azaltılması adına müdahale bulunuyorsa, yurttaşların ortak iyisini gerçekleştirmeye çalışıyor demektir. Bireylerin özgürlügünü̈ arttırmak için yapılan böyle müdahaleler ortak iyiye katkı sağladıkları için keyfi bir temele sahip değillerdir ve bu nedenle de meşru eylemlerdir (Ergüç 2016, 58).

Cumhuriyetçilerin, kişilerin eylem seçeneklerinin niceliksel fazlalığının onları özgür yapmadığı iddiasını anlamak için ise müdahalesiz tahakkümün ne olduğuna bakmak gerekir. Daha önce de belirttiğim gibi, cumhuriyetçi özgürlük anlayışına göre tahakküm, fiili bir müdahalenin var olmadığı durumlarda da kişiler arasındaki bir ilişkiyi belirleyebilir. Böyle bir tahakküm ilişkisi içinde de, tahakküm altında tutulanlar özgürlüklerinden taviz verirler (Pettit 1998, 94-96). Üzerinde tahakküm kurulan kişi, kendisine doğrudan müdahale edilmediği durumlarda eylem seçeneklerinin arttı̆̆ını görebilir. Fakat böyle bir artış, bu kişiyi daha özgür yapmaz. Yukarıda bahsedilen niceliksel-niteliksel ayrımını göz önüne alarak söylersek, cumhuriyetçiler, kendisine müdahale edilmeyen bir kişinin eylem seçeneklerinin niceliksel olarak en yüksek seviyeye çıkmış olması durumunda bile, eğer bu söz konusu kişi tahakküm altında bulunuyorsa, onun eylem seçeneklerinin niteliğinin oldukça azalmış olduğunu söyleyeceklerdir (Pettit 1998, 95). Örneğin, iyi huylu bir efendisi olan kölenin eylem seçenekleri, kendisine müdahale edilmediği oranda niceliksel olarak artar. Fakat o, her zaman, yapmak istediklerini yapmaya kalkışmadan önce efendisinin kendisi üzerindeki tahakkümünü göz önüne almak zorundadır. Çeşitli eylemleri gerçekleştirirken ihtiyatlı davranmak ve efendisinin 'yoluna çıkmamak' zorundadır. Böylesi bir düşünsel arka plan, kölenin bütün eylem seçeneklerini belirler; yani bu söz konusu eylem seçeneklerinin niteliksel olarak azalmasına yol açar.

Tahakküm altında bulunan bir kişi, eylem olanaklarının niteliksel olarak azalmasının ötesinde bir tehlikeyle daha karşı karşıyadır. Cumhuriyetçiliğe göre, bu kişinin eylem seçenekleri niceliksel olarak oldukça yüksek olsa bile, bu niceliksel fazlalığın korunmasının bir garantisi yoktur (Pettit 1998, 122). Böyle bir niceliksel fazlalığın sürekliliği hiçbir zaman kesin değildir. Müdahalenin gerçekleştirilip gerçekleştirilmemesi, sıklığı ve yoğunluğu her zaman tahakküm kuranın isteğine bağlı olduğu için, müdahalesiz tahakküm ilişkisi, insanları daha özgür yapmaz. Tahakkümsüzlük olarak özgürlük ise bu tarz bir ilişkiyi ortadan kaldırmayı hedeflediği için, kişiyi, kendisine keyfi müdahalede bulunulması ihtimalinden korur ve böylece onun eylem seçeneklerinin niteliğini arttırır.

Bir kişi üzerinde tahakküm kuran kişi, ona fiili olarak keyfi bir müdahalede bulunmasa da, böyle bir müdahaleyi gerçekleştirme gücüne her zaman sahiptir. Bir asimetrik güç ilişkisi olan tahakküm, üzerinde tahakküm kurulanın her zaman aleyhine işleyen bir bağımlılık ilişkisi yaratır (Pettit 1998, 123). Kendisine birisi tarafindan keyfi temelde müdahale edilme ihtimalinin olduğu bir durumda, kişi bu söz konusu insana bağımlı demektir. Bu bağımlılık durumu, tahakküm kuranın, tahakküm kurduğu kişilere karşı gösterdiği iyi niyet ile yok olabilecek bir olgu değildir. Tahakküm kuran kişinin iyi niyeti ve müdahale etmedeki isteksizliği, onun, sadece müdahalede bulunma ihtimalini azaltır. Fakat üzerinde tahakküm kurduğu kişilere her an müdahale etme olasılığ var olmaya devam ettiği için, tahakküm ilişkisi, üzerinde tahakküm kurulanların özgürlüğünü azaltan bir ilişki biçimi olarak var olmaya devam eder.

Müdahalesiz tahakküm ilişkileri içindeki kişiler, ayrıca, eylem olanaklarını her zaman tahakküm ilişkisindeki konumları üzerinden değerlendirmek zorunda kalırlar. Bütün eylemlerini, 'efendilerinin' tavır ve düşüncelerini göz önüne alarak gerçekleştirmek zorunda olmaları, 
onların eylem seçeneklerini büyük ölçüde kısıtlar (Skinner 1998, 72). Bu tarz bir kısıtlama, fiziksel ya da psikolojik müdahalelerin sonucunda yaratılan koşulların ürünü olmasa da, tahakküm altındaki kişilerin özgürlügünü azaltır. Burada söz konusu olan, dışarıdan yapılan müdahaleler değil, böyle müdahalelerin gerçekleştirilmesi ihtimalinin var olması sonucunda oluşan kendini kısıtlama durumudur. Tabii ki, böyle bir kendini kısıtlama durumunun oluşması için, tahakküm altında olan kişinin bu asimetrik güç ilişkisinin varlığını ve kendisinin bu ilişkideki konumunu bilmesi zorunludur.

\section{Bir İdeal Olarak Tahakkümsüzlük}

Tahakkümsüzlüğün tanımını yapmak ve onun özelliklerini açıklamak, bize tahakkümsüzlük olarak özgürlügün nasıl bir ideal olduğunu ve cumhuriyetçilerin böyle bir ideale ulaşmak için çaba gösterilmesi gerektiğine dair iddialarını anlamak konusunda yardımcı olur. Cumhuriyetçi politik özgürlük ideali, yani tahakkümsüzlük, cumhuriyetçiler tarafından her şeyden önce toplumsallık olgusunun göz önüne alınmasını gerektiren bir ideal olarak anlaşılır (Skinner 1984, 195-199; Pettit 1998, 164-165; Honohan 2002, 8; Maynor 2003, 20-29; Baştürk 2013, 125; Lovett 2014). Yani o ancak insanların toplumsal yaşamda ve birbirleriyle girdikleri ilişkiler içinde gerçekleştirilebilir. Cumhuriyetçi özgürlük yaklaşımının iddiası, bir kişinin toplumdaki diğer insanlardan soyutlanmış bir şekilde yaşayarak özgür olmasının mümkün olmadığıdır. Tahakküm ilişkilerinin her zaman toplumsal bir temeli olması gibi, tahakkümsüzlük de sadece toplumsal bir ideal olarak düşünüldüğüne gerçekleştirilebilir. Yani insanların özgür yaşamalarının koşulu, toplumsal ilişkilerde tahakkümün yok olmasıdır. Cumhuriyetçiler, toplumsal bir ideal olan tahakkümsüzlüğün tersine müdahalesizlik olarak özgürlük yaklaşımının, toplumdan izole bir yaşam kuran bir kişinin mutlak özgürlüğü elde edebileceği düşüncesine zemin hazırladığını iddia ederler (Pettit 1998, 119). Çünkü bir insan, idealde, mutlak anlamda müdahalesizlik durumuna ancak diğer insanlardan tamamen uzakta yaşayarak ulaşabilir. $\mathrm{Bu}$ durumdaki kişi müdahaleden tam anlamıyla uzak, yani tam olarak özgürdür. Cumhuriyetçiliğin, müdahalesizlik olarak özgürlük yaklaşımına eleştirisi, onun kişiler arası ilişkiler ve statüler ile bu ilişkilerin ve statülerin insanların özgürlüğüne etkilerini göz ardı ettiğidir.

Tahakkümün asimetrik bir güç ilişkisi olmasına benzer şekilde, tahakkümsüzlük de bir çeşit güç ilişkisidir. Fakat bir ideal olarak tahakkümsüzlüğün tam anlamıyla gerçekleştirilebilmesi için, bu güç ilişkisindeki tarafların birbirlerine bağımlı olmamaları ve kendilerine uygulanma riski olan keyfi temelde müdahalelere karşı çıkabilme gücüne sahip olmaları gerekir. Yani tahakkümsüzlüğün gerçekleştirildiği ilişki, simetrik bir güç ilişkisidir. Bir ilişkide tahakküm altına alınma olasılığı bulunan kişinin böyle bir riske karşı koyabilme ve kendini koruyabilme gücü, tahakkümü engelleyen koşuldur. Tahakkümsüzlük olarak özgürlük anlayışında güce yapılan bu vurgu nedeniyle, Pettit onun pozitif özgürlük yaklaşımı ile benzerlikler taşıdığını iddia eder (Pettit 1998, 43).

Tahakkümsüzlügün yukarıda bahsedilen iki özelliği, yani toplumsallığı ve bir güç ilişkisi olarak var olması dikkate alındığında bu ideal kısaca şöyle tanımlanabilir: "hiç kimsenin insafına kalmadan başka insanlarla birlikte yaşama durumu" (Pettit 1998, 115). Her politik ideal gibi tahakkümsüzlük de, insanların ulaşmak istedikleri ve gerçekleştiği takdirde insanlara fayda sağlayacak bir iyi olarak kurgulanır. Cumhuriyetçi özgürlük ideali, Pettit tarafından hem araçsal bir iyi hem de birincil bir iyi olarak ortaya konmaya çalışılır.

Tahakkümün araçsal bir iyi olması, onun, toplum içindeki bireylerin kendi amaçlarını gerçekleştirmelerini ve kendi isteklerinin peşinden koşmalarını mümkün kılan ya da kolaylaştıran bir iyi olması demektir. Cumhuriyetçi politik özgürlük bu yanıyla müdahalesizlik olarak 
özgürlüğe benzer. Müdahalenin yokluğu da, tahakkümün yokluğu gibi, bireylerin kendi isteklerini tatmin etmeleri ve kendi mutlulukları için yapmak istediklerini yapmaları için bir araç olarak düşünülür. Fakat tahakkümsüzlüğün araçsal bir iyi olarak kurgulanması ve çeşitli özelliklerinin açıklanması, onun neden toplumdaki bütün bireyler tarafindan arzulanması gereken bir iyi olduğunu açıklamaz. Her siyaset teorisi, ortaya koyduğu ideallerin, diğer politika teorilerinin ortaya koyduğu ideallerden neden ve nasıl daha iyi ve istenilebilir olduğunu temellendirmek zorundadır. Pettit (1998, 119-130), bu amaçla, cumhuriyetçi özgürlük idealini müdahalesizlik olarak özgürlük idealiyle kıyaslar ve tahakkümsüzlügün, müdahale edilmemeye göre üç üstünlüğü olduğunu iddia eder.

$\mathrm{Bu}$ üstünlüklerden ilki, tahakkümsüzlük idealinin amacının müdahale riskini tamamen ortadan kaldırmak olmasıdır. Çünkü Pettit'e $(1998,122)$ göre, tersine, müdahalesizlik bir ideal olarak ortaya konduğunda bu risk göz ardı edilmiş olur. Tahakkümsüzlügün gerçekleştirilmeye çalışıldığı durumlarda, keyfi müdahalede bulunma gücü mümkün olduğunca azaltılmaya çalışılır ve böylece tahakkümün var olmadığı bir ilişkide taraflar arasında, iki tarafın da birbirine üstün gelemeyeceği bir güç dengesi yaratılır. Müdahalesizlik olarak özgürlük anlayışı ise, böyle müdahalelerin fiili olarak ortaya çıktığı durumları azaltmak için çaba harcar. Ama mevcut müdahalesizliğin azami seviyede olduğu bir durumda bile, bir kişiye keyfi temelde müdahalede bulunulma riski oldukça yüksek olabilir. Eğer ortada bir tahakküm ilişkisi varsa, tahakküm altında olan bir kişiye müdahale edilmemesi, birçok durumda şansa bağlı olacaktır. Pettit, böylesi bir belirsizlik durumunun, cumhuriyetçi özgürlük yaklaşımı için kabul edilemez bir durum olduğunu söyler. Belirsizliğin var olması, keyfi müdahale ihtimalinin de var olmas1 demektir ve böyle bir ihtimal var olduğu sürece, insanlar asla tam anlamıyla özgür olamazlar. Pettit bu söylenenlerden şöyle bir sonuç çıkartır: Tahakkümün olmadığı bir ilişkide kişilerin sahip olduğu özgürlük sağlam temellere dayanırken, müdahalesizlik olarak düşünülen özgürlük durumu dayanıklı ve kalıcı değildir.

Cumhuriyetçi politik özgürlüğün bir ideal olarak müdahalesizlik karşısındaki ikinci üstünlüğüne dair iddia, birincisi ile yakından ilişkilidir. Tahakkümün özelliklerini aktarırken de belirttiğim gibi, müdahale edilme riskinin varlığı tahakküm altında olan kişilerin kendilerini kısıtlamalarına yol açar. Bu kişilerin, eylem seçeneklerini değerlendirirken dikkatli davranmaları gerekliliği ve üzerlerinde tahakküm kuran insanların hareketlerini ve düşüncelerini gözlemleyip buna göre hareket etme zorunlulukları, onların eylem seçeneklerini niteliksel olarak azaltır. Pettit'e (1998, 123-124) göre tahakkümsüzlük ideali, tam da kişilerin eylem seçeneklerindeki böylesi bir niteliksel azalışı yaratan koşulları ortadan kaldırmaya çalıştı̆̆ için, eylem seçeneklerinin niteliksel olarak azalmasıyla ilgilenmeyen müdahalesizlik idealinden üstündür.

Nasıl ki tahakküm iliş̧isinin var olmasının önkoşullarından birisi, bu iliş̧inin ortak bilginin nesnesi haline gelmesiyse, aynı koşul tahakkümün olmadığ Tahakkümsüzlük bir ideal olarak alındığında oluşturulmak istenen ilişkiler, yani insanların birbirleri üzerinde tahakküm kurmadığ ilişkiler her zaman toplumsal yaşamda görünür ve bilinir olurlar. İşte kişiler arası ilişkilerin bu özelliği, Pettit (1998, 102-105) için, tahakkümsüzlük idealinin müdahalesizlik idealinden daha üstün olmasının üçüncü nedenidir. İnsanlar arası ilişkilerde tahakkümün ortadan kalkması durumu, bu ilişkinin dışındaki kişiler tarafından da bilinir. Bu ise, bir kez oluştuğunda, bu tarz ilişkilerdeki simetrik güç dengesinin bozulmasının oldukça zorlaşması anlamına gelir. Bir ilişkide tahakkümün oluşması, sadece bu ilişkinin tarafı olanlar tarafından değil, bu ilişkiyle dolaylı olarak bağlantı kuranlar tarafından da engellenebilir. Fakat bunun tersine, cumhuriyetçi teoriye göre, müdahalesizlik idealini 
gerçekleştirebilmiş, yani liberal özgürlük yaklaşımına göre tam olarak özgür olabilmiş bir kişi, bu konumu yasal olarak güvence altında olsa bile, herhangi bir müdahale sonucunda özgürlüğü tehlikeye girdiğinde kendisi dışında herhangi birine güvenemez. Çünkü onun özgürlüğü ve bu özgürlük sayesinde elde ettiği konumu, kendisiyle aynı toplumda yaşayan diğer insanların ortak bilgisi dâhilinde olmayabilir.

Özetlemek gerekirse Pettit, cumhuriyetçi özgürlük idealinin, kişilerin eylem seçeneklerinin niceliksel artışını sağlama konusunda müdahalesizlik olarak özgürlük idealinin gerisinde kalsa da, insanlara birbiriyle bağlantılı üç alanda liberal özgürlük idealinden daha çok yarar sağlayabileceğini öne sürer:

Tahakkümsüzlük olarak özgürlük bir kişiyi belirsizlikten ve beraberinde getirdiği endişe ile plan yapma aczinden; riayet etmek ve çeşitli hamlelerini önceden kestirmek zorunda kalarak güçlüyle ilişkide birtakım stratejilere başvurma ihtiyacından, ve kişinin başkasının keyfi müdahale ihtimali karşısında savunmasız olduğuna -yani, muhtemelen böyle yapmayacak bile olsalar, müdahale yapabilecek bir başkasının var olduğuna- iliş̧kin ortak bir bilince uygun düşen bağımlılıktan kurtarmayı vaat eder (Pettit 1998, 126).

Bir ideal olarak tahakkümsüzlük, araçsal bir iyi olması dışında birincil de bir iyidir. Yani Pettit'e $(1998,127-130)$ göre tahakkümsüzlük, sadece toplumdaki insanların kişisel isteklerini gerçekleştirmeleri için bir araç değildir; o aynı zamanda bu isteklerin gerçekleşebilmesinin zorunlu koşullarından biridir. Tahakkümsüzlük idealinin gerçekleşmesi için, insanlar arası ilişkilerde belirsizliğin azaltılması, kişilerin kendilerine uygulanma ihtimali olan keyfi müdahalelerden korunmak için daha temkinli davranmak zorunda kalmalarının engellenmesi ve kişilerin kendileri üzerinde tahakküm kurma girişimlerine karş1 çıkacak bir güce sahip olmalarının sağlanması gerekir. Ama insanların bu söz konusu avantajlara sahip olmaları için de, toplumdaki tahakküm ilişkilerinin büyük oranda ortadan kalkmış olması bir zorunluluktur. Yani tahakkümsüzlük, araçsal bir ideal olarak gerçekleştirilmeye çalışıldığında, insanlara çeşitli yararlar sağlar ve insanlar, sağlanan bu yararlar sayesinde kendi isteklerinin peşinden koşma şansı bulurlar. Ama aynı zamanda o, birincil bir iyi olarak, insanların bu avantajlara sahip olabilmelerinin zorunlu koşullarından biridir. Çünkü insanların kişisel iyilerini gerçekleştirebilme şansları, onların özgürce plan yapabilme ve eyleyebilme gücüne bağlıdır ve tahakkümsüzlük durumu, insanlara bu gücü sağlar. Hayatının herhangi bir alanında başkalarına bağımlı yaşayan bir insanın kendi isteklerini gerçekleştirme şansı yoktur.

\section{Sonuç}

Philip Pettit'in sistematik bir tarzda geliştirmeye çalıştığı cumhuriyetçi özgürlük yaklaşımı, yine onun tarafından tahakkümsüzlük olarak özgürlük şeklinde ortaya konmuştur. Pettit, tahakkümün keyfi temelde gerçekleştirilen müdahaleler ya da söz konusu müdahalelerde bulunma gücüne sahip olunması sonucunda ortaya çıktığını ve bireylerin gerçek özgürlüğünün ancak toplumdaki tahakküm ilişkilerinin yok edilmesiyle gerçekleştirilebileceğini söylemiştir.

Her müdahalenin özgürlüğe zarar vermediğini, yalnızca tahakküme yol açan müdahalelerin insanların özgürlükleri için tehdit oluşturduğunu, yani tahakkümsüz müdahalenin mümkün olduğunu iddia eden Pettit, bu düşüncesini özgürlüğün koşullanması ile özgürlükten taviz verilmesi olarak kavramlaştırdığı bir ayrıma dayandırır. Ona göre keyfi temelde olmayan, yani müdahale edilenlerin çıkarlarını göz önüne alan müdahaleler kişilerin eylem olanaklarını sadece niceliksel olarak kısıtlarlar; yani bu kişilerin özgürlükleri yalnızca koşullanır. Bunun tersine 
keyfi temelde müdahalelere maruz kalan ya da maruz kalma riski bulunan bireyler özgürlüklerinden taviz vermişler demektir. Çünkü söz konusu bireylerin bir tahakküm ilişkisinin sonucunda, bu ilişki fiili müdahalelere dayanmasa da, eylem olanakları niteliksel olarak kısıtlanmıştır.

Pettit'e göre, yoğunluğu ve kapsamı her özgül durumda değişiklik gösteren ve kişiler ya da gruplar arasındaki toplumsal bir güç ilişkisi olarak anlaşılması gereken tahakküm, bu özellikleri nedeniyle, tahakkümsüzlük olarak özgürlüğü müdahalesizlik olarak özgürlükten daha üstün bir ideal haline getirir. Tahakkümsüzlük olarak özgürlük, sadece keyfi temelde müdahaleleri değil aynı zamanda böyle müdahalelere maruz kalma riskini de ortadan kaldırmayı hedefler. $\mathrm{Bu}$ hedefi sayesinde insanların eylem olanaklarını niteliksel olarak artırmaya çalışır ve tahakkümün toplumsal yanı aracılığıyla tahakkümsüzlüğün toplumun tamamı tarafından bilinmesini ve denetlenmesini sağlayacak araçlar geliştirmek için yollar arar.

$\mathrm{Bu}$ çalışmada Pettit'in cumhuriyetçiliğe yaptığı katkıları incelemeye çalıştım. Onun ortaya koyduğu tahakkümsüzlük olarak özgürlük anlayışı, hem tahakkümü toplumsal bir güç ilişkisi olarak kavrayarak, hem de tahakkümsüz müdahale ve müdahalesiz tahakküm olgularını kavramlaştırarak cumhuriyetçi siyaset teorisine önemli katkılarda bulunmuştur. İnsanın eylem seçeneklerinin niceliksel ve niteliksel olarak azaltılması arasında ayrım yapan Pettit, hem ortak iyiye dayanan, yani keyfi temelde olmayan müdahalelerin kişinin özgürlüğünü sadece niceliksel olarak sınırlandırdığını ve bu nedenle söz konusu müdahalelerin meşrulaştırılabileceklerini söylemiş, hem de insan özgürlüğünün fiili bir müdahale olmadan da gerçek anlamda kısıtlanabileceğini belirtmiştir. Böyle bir yaklaşım ise, liberal siyaset teorisinin kendi müdahalesizlik idealine dayanarak ortaya koyduğu, birey ile toplum arasındaki zıtlık iddiası karşısında, alternatif bir toplum-birey ilişkisi anlayışını savunmada önemli bir başlangıç noktası olacaktır. 


\section{BİBLİYOGRAFYA}

Baştürk E. 2013, "Çağdaş Siyaset Felsefesinde İki Tarz-1 Cumhuriyetçilik: Atina ve Roma Anlayışlarının Karşılaştırılması”. Uşak Üniversitesi Sosyal Bilimler Dergisi 6/1, 111-130.

Berlin I. 1958, “Two Concepts of Liberty”. Four Essays on Liberty (1969) 118-172. Oxford.

Carter I. 2008. "How are Power and Unfreedom Related?”. Eds. C. Laborde \& J. Maynor. Republicanism and Political Theory, 58-82. Malden, MA.

Costa M. V. 2007, "Freedom as Non-Domination, Normativity, and Indeterminacy". Journal of Value Inquiry 41, 291-307.

Ergüç V. 2016, “Cumhuriyetçilik Düşüncesinde Özgün Bir Yaklaşım: Philip Pettit ve Tahakkümsüzlük Olarak Özgürlük”. Üsküdar Üniversitesi Sosyal Bilimler Dergisi 3, 37-63.

Gaus G. F. 2000, Political Concepts and Political Theories. Boulder.

Haakonssen K. 1993, “Republicanism”. Eds. R. E. Goodin \& P. Pettit. A Companion to Contemporary Political Philosophy, 729-735. Oxford.

Hobbes T. 2008, Leviathan. İstanbul 2008.

Honohan I. 2002, Civic Republicanism. London.

Knowles D. 2001, Political Philosophy. London.

Lovett F. 2012, "What Counts as Arbitrary Power?”. Journal of Political Power 5, 137-152.

Lovett F. 2014, "Republicanism". The Stanford Encyclopedia of Philosophy (Winter 2014 Edition).

Kaynak: http://plato.stanford.edu/archives/win2014/entries/republicanism/.

Maynor J. W. 2003, Republicanism in the Modern World. Cambridge.

Mill J. S. 2014. Özgürlük Üstüne ve Seçme Yazllar. İstanbul.

Pettit P. 1989, “The Freedom of the City: A Republican Ideal”. Eds. A. Hamlin \& P. Pettit. The Good Polity, 141-168. Oxford.

Pettit P. 1996, "Freedom as Antipower". Ethics 106, 576-604.

Pettit P. 1997, Republicanism: A Theory of Freedom and Government. Oxford.

Pettit P. 1998, Cumhuriyetçilik: Bir Özgürlük ve Yönetim Teorisi. İstanbul.

Pettit P. 1999, “Republican Freedom and Contestatory Democratization”. Eds. I. Shapiro \& C. HackerCordon. Democracy's Value, 163-190. Cambridge.

Pettit P. 2003, “Agency-Freedom and Option-Freedom”. Journal of Theoretical Politics 15, 387-403.

Pettit P. 2004, “The Common Good”. Eds. K. Dowding, R. Goodin \& C. Pateman. Justice and Democracy: Essays for Brian Barry, 150-169. Cambridge.

Pettit P. 2005, “The Domination Complaint”. Nomos 86, 87-117.

Pettit P. 2011, “The Instability of Freedom as Noninterference: The Case of Isaiah Berlin”. Ethics 121, 693-716.

Skinner Q. 1984, “The Idea of Negative Liberty”. Eds. R. Rorty, J. B. Schneewind \& Q. Skinner. Philosophy of History: Essays on the Historiography of Philosophy, 186-212. Cambridge.

Skinner Q. 1986, “The Paradoxes of Political Liberty”. Ed. S. McMurrin. The Tanner Lectures on Human Values, Volume VII, 225-250. Cambridge.

Skinner Q. 1990, “The Republican Ideal Of Political Liberty”. Ed. G. Bock, Q. Skinner \& M. Viroli. Machiavelli and Republicanism, 293-309. Cambridge.

Skinner Q. 1998, Liberty Before Liberalism. Cambridge.

Skinner Q. 2002, “A Third Concept of Liberty”. Proceedings of the British Academy 117, 237-268.

Skinner Q. 2008, "Freedom as the Absence of Arbitrary Power". Eds. C. Laborde \& J. Maynor. Republicanism and Political Theory, 83-101. Malden, MA.

Tunçel A. 2010, Bir Siyaset Felsefesi: Cumhuriyetçi Özgürlük. İstanbul. 